\title{
住宅のリビングとダイニングとの間の床段差が \\ プライバシー意識とコミュニケーション意識に及ぼす影響 \\ THE INFLUENCE OF THE DIFFERENCE OF FLOOR-LEVEL BETWEEN ROOMS IN A HOUSE ON THE SENSE OF PRIVACY AND COMMUNICATION
}

\author{
金 銀 熙*, 宗方 淳**, 平手小太郎*** \\ Eunhee KIM, Jun MUNAKATA and Kotaroh HIRATE
}

\begin{abstract}
The aim of this study is to understand the influence of difference of levels within the same floor of house on the sense of privacy and communication among family. We conducted two experiments, the Field Experiment and the Image Experiment. First, We compared the sense of privacy and communication in detached housings with and without 'skip-floor' territory between living and dinning space, in the Field Experiment.The result indicates that a skip floor has the effects on occupants' perception, for instances, a variety of space, softening the feeling of privacy disturbance, being conscious of the presence of other family members, and comfort to start communication. Next, we conducted the Image Experiment by computer graphics for the purpose which shows clearly whether the result of the field experiment is the influence by the floor level difference. we obtaind the result that the significant difference was checked in the sense of privacy between the higher and the lower stage, on the Evaluation factor and the Privacy factor.
\end{abstract}

Keywords : A Difference of Floor-level, Sense of Privacy, Sense of Communication, Field Experiment, Image Experiment 㦿段差，プライバシー意識，コミュニケーション意識，現場実験、画像実験

\section{1.はじめに}

床段差は床面の高さを変化させることによって空間を区切るデザ インの一つの手法として用いられている。例えば、古代神殿や神社 などの宗教建築では俗と聖を区切り、宮殿建築などでは身分の上下 を区切り階層性を生み出している1)。現代建築では地形の高低差の処 理を目的で設けられたりデザインの巧みさを示すためにも頻繁に用 いられている2)。これらの例は、床段差が主にその物理的な形態から 受ける象徴的な意味や設けられる経緯及び目的に関して述べられた ものである。一-方、林段差が空間を造る要素である以上、林段差の もつ空間がその空間を使う人間にとっては心理的にどのような意味 を持ち、行動にはどのような影響を及ぼすかに対する研究が求めら れている。まず、込山らは床段差の高さを変数に実験による印象評 価及び居場所の選択への影響を評価している ${ }^{31}$ ，注11。同じく高橋らは 床段差の平面形態を变数に実験による印象評価及び居場所の選択へ の影響を評価している゙!。

一方、以上の二つの研究の居場所実験で被験者が段差部分と段の 上と下に分かれる結果や、込山らの言う床段差を設ける目的のうち 「曖昧な空間分節」（視覚的に連続しているが異なる二つの空間とし ても利用したいと思うこと） ${ }^{31}$ から考えると、床段差がある空間は、
一人が分けられた空間を行動に合わせ使い分けることに限らず、二 人以上の人が同時に各自の行動に合わせ空間を使い分けることも考 えら机る。すると、林段差の及ぼす心理的影響は個人個人が空間に 対して感じる印象に限らず、分けられた各空間を利用する人同士で お互いに対して感じる印象にも関係すると考えられる。この問題に 対する研究としては、橋本らによるレベル差が心理的領域に及ぼす 影響をみた研究らをを举げられる。しかし、これいは相手に対する対人 距離からみる心理的領域に関する研究の一連として、被験者同士の 上下の位置関係から感じる対人距離をみたものであり、またお互い 向き合っている状況を設定しているため、普段、林段差により分け ら扎た各空間を使い分けている人同士が、お互いに対して感じる印 象とは異なるといえる。このように、分けら机た各空間を利用する 人に注目して床段差による心理的影響を探る研究はまだ十分とは言 えない。

以上のことから、本研究では、お互いに対して感じるプライバ シ一意識とコミュニケーション意識に着目し、それらと床段差との 関係を明らかにすることを目的とする。

ここでプライバシー意識とコミュニケーション意識に着目したこ とは、込山らのいう「曖昧な空間分節」 ${ }^{3)}$ に基づいたものである。「曖
${ }^{*}$ 東京大学大学院工学系研究科建築学専攻 博士課程 (工修)

** 千葉大学大学院工学研究科建築・都市科学専攻 准教授 博士 (工学)

*** 菄京大学大学院工学系研究科建築学尃攻 准教授 $\cdot$ 工博
Candidate for Doctor, Dept. of Arch., Grad. Sch. of Eng., The University of Tokyo, M. Eng. Assoc. Prof., Dept. of Arch. and Urban Sci., Grad. Sch. of Eng., Chiba Univ., Dr. Eng. 
昧な空間分節」は床段差のもつ「区切る」ことと「盤ぐ」ことの両 面性を意味すると考えら扟る。さらに、建築構法においても、床段 差は視覚的な繋がりを多く持ちながらも、両空間の間の水平距離を 最も短く繋いでいると言える注2)。このように床段差により区切られ る空間は、区切られたどの空間よりも、両領域を強く繋いでいると 考えられる。これを分けられた各空間にいる人同士に当てはめると、 床段差のある空間は人間関倸を「区切る」ことと「繋ぐ」ことに働 くと考えられる。そして人間関係を「区切る」ことはブライバシー 意識に、「繋ぐ」ことはコミュニケーション意識に影響を及ぼすので はないかと考えられる。

本段差の設けられた空間としては、日常生活で滞在する時間が最 も長く、最もブライバシーが高い空間である住宅を対象にすること にした。また、住宅での床段差は、主にリビングルーム（以下Ｌと する）とダイニングルーム（以下 D とする）の間に最も多く設けら れている注31ことから、L とD の間の床段差がLD 間で感じるブライバ

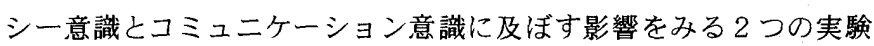
(現場実験と画像実験) を計画した。評価指標としてはLD 間でお互い の空間にいる家族に対して感じる印象として、ブライバシ一意識は 「気になる」程度注なを、コミュニケーション意識は「声をかけやす い」程度を用いることにした注ら。

\section{2. 現場実験}

\section{2-1. 実験概要}

まず、住宅展示場の実空間を利用した印象評価実験を計画した。 実際の住宅でL D 間の木段差は、階段.つ程度の高さから完全に違う 階と見られるスキップフロアに至るまで、様々な形態で存在する。 そこで、床段差が最も大きいと考えら机るスキップフロア(以下 SF と する) タイプと、・般的に多く見られるLDが‥つに縏いでいるタイプ を実験対象空間として選択し、两実験対象空間の印象を比較するこ とにした。なお、林段差のある空間に対する印象として、プライバ シ一意識とコミュニケーション意識と同時にL D 間の構成方式に対す る空間自体の印象を評価することにした。これは、込山らの他の要 因が制御された実験空間においての印象評価の結果 ${ }^{31}$ と、実物住宅空

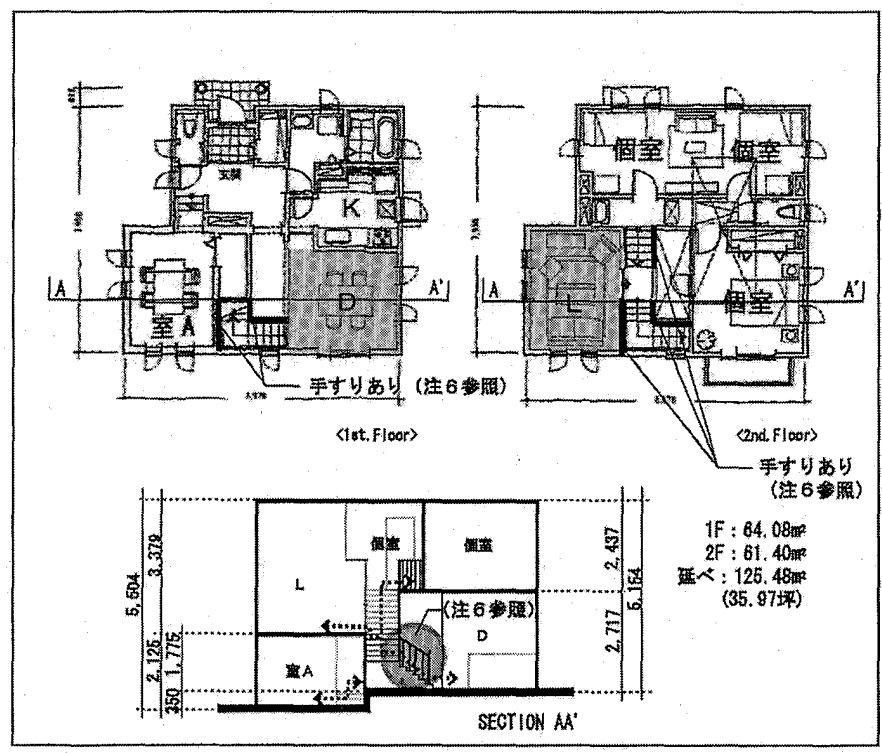

図 $1 「 S F$ 型」(Aモデル)
間においての印象を比較する目的のためである。

実験は、T社の住宅展示場のAモデル（LDK がSF で構成されてい る、以下「SF 型」とする）と、Yモデル（LDKが・つに繋がっている、 以下「-体型」とする) を実験対象にして行った(図 1, 図2) 注6)。こ れらの実験対象は T 社の顧客が実際の宿泊体験ができるものである。 そこで 2005 年 9 月から 2006 年 2 月まで 泊宿泊体験を行った・般人 を対象に印象評価を行った。なお両実験対象は共用空間以外の室構 成という点でほぼ共通しており注7，LD間の床段差による影響を比較 できると考えら机る。両実験対象のデー夕の均衡が得られなかった ため、空間に対する意識が高い建築専攻の大学院生と、両実験対象 の空間を体験したことのあるT社の社員を対象として追加した注8）。 なお大学院生と $\mathrm{T}$ 社の社員は同…人が両タイブの印象評価を繰り返 し行った (表 1)。

実験方法は、宿泊体験者は宿泊体験した実験対象に対して宿泊体 験後に、他の被験者は両実験対象を 10 分間自由に体験した後にLゃ Dにて、LとD間の構成方式に対する印象とプライバシー意識及び コミュニケーション意識に関してアンケートに答えてもらった。ア ンケートの内容を表 2 に示す。

\section{2-2. 分析及び結果}

両実験対象の L D の構成方式及びプライバシー意識とコミュニケー ション意識に対する印象評価を比較した結果、被験者属性（宿泊体験 者 / 大学院生 / $\mathrm{T}$ 社の社員)による有意差は見られなかった(いずれの 評価項目においても p 值は 0.43 以上)。従って以下、すべての属性の 被験者のデータをまとめて分析した。

\section{1) LDの構成方式}

両実験対象のL D の構成方式に対して気に入るか気に入らないかを

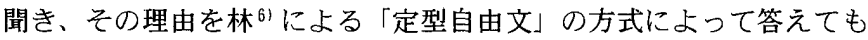
らった。その記述内容を分類・整理のうえ評価構造で表した結果を 図 3 に示す。その内容を以下に挙げる。

(1)「SF 型」のLD 間がSF で分けられていることは以下のような評価に 媻がることが分かった。

- 家中全体が見えることから家族の様子を分かりやすく安心を感じ る。

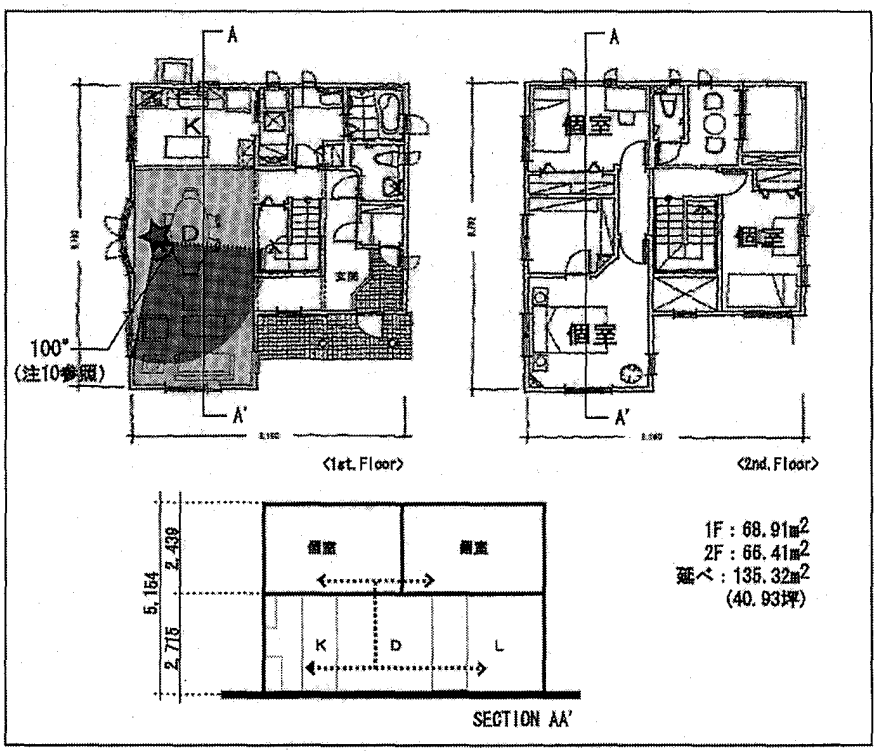

図 2 「一体型」(Yモデル) 
表 1 実験対象別の被験者構成

\begin{tabular}{|c|c|c|c|c|c|c|c|}
\hline \multirow{3}{*}{ 被験 者 } & \multicolumn{5}{|c|}{ 人数（人） } & \multicolumn{2}{|c|}{ 年 踣 （歳） } \\
\hline & \multicolumn{2}{|c|}{ SF 型 } & \multicolumn{2}{|c|}{ 一体梨 } & \multirow{2}{*}{ 合計 } & \multirow{2}{*}{ 平均 } & \multirow{2}{*}{$\begin{array}{c}\text { 標 準 偏 } \\
\text { 差 }\end{array}$} \\
\hline & 男 & 女 & 男 & 女 & & & \\
\hline 一般宿泊体験者 & 2 & 6 & 9 & 13 & 30 & 32.6 & 12.0 \\
\hline 大学院生 * & 5 & 6 & 4 & 6 & 21 & 27.4 & 3.4 \\
\hline T社社員 * & 2 & 4 & 2 & 4 & 12 & 31.8 & 6.2 \\
\hline 小計 & 9 & 16 & 15 & 23 & $\overline{63}$ & 31.3 & 10.2 \\
\hline 合計 & & & & & 63 & 31.3 & 10.2 \\
\hline
\end{tabular}

表 2 アンケートの内容

\begin{tabular}{|c|c|}
\hline 咩価項目 & \begin{tabular}{|c|} 
評価指標 \\
\end{tabular} \\
\hline 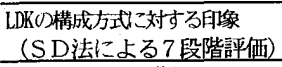 & \begin{tabular}{|l|} 
LDの構成方式が気に入る? \\
டってい理由を定型自由記述文こより詁术
\end{tabular} \\
\hline $\begin{array}{l}\text { プライバシ一意識湆 } \\
\text { (SD法こよる7段階評洒) }\end{array}$ & 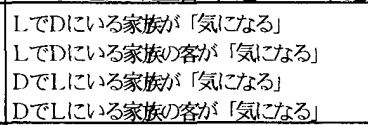 \\
\hline 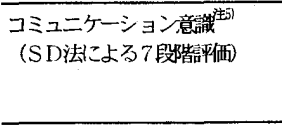 & 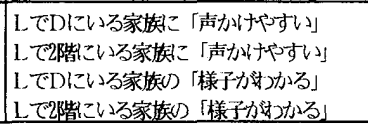 \\
\hline
\end{tabular}

- 家中が繋がっていることとL の天井が高い空間が得られるることら 家族の気配を感じ開放感を感じる。

- 空間にメリハリがあると感じることから広く感じ安らげる。

一空間が面白いと感じることから格好よく活気を感じる。

- 空間が分けられていることから狭く感じる。

一階段が多くなることから使いにくいと感じる。

以上から、林段差があることは同一空間を狭くも広くも感じさせ る、つまり、視覚的に分離され狭く見えても、空間にメリハリがあ
るすなわち各空間に個性や特徵があると感じることから心理的に広

くも感じることが分かった。

(2)「-・体型」のLD間が一つに繋がっていることは以下のような評価 に繋がることが分かった。

一広い空間が得られることから開放感を感じ，安らげ，空間の使い勝 手がよく，大勢の人が集まったときに良い。

-LD 間で家族の様子を分かりやすく，家事に孤独を感じなく，掃除が 便利である。

一台所が丸見えであることから来客時にプライバシーが守れなく，家 中に料理の匂いが長く残るのが気になる。

ーLD間で家族の行動が気になり落ち着いて集中しづらい。

一気持ちのメリハリがつかない。

\section{2) プライバシー意識注41, 注91}

両実験対象のLD 間で感じるブライバシー意識を、自分がL または D にいるときD またはL にいる家族や家族の客がどれほど気になるか を答えさせるという方式で評価させた。各評価の全被験者平均值を 図 4 に示す。状況・条件別比較を行い判明した結果を以下に挙げる。

(1)家族より家族の客がより気になる（p<0.01）。

(2)「SF·型」が「・体型」より、家族が気になる程度を和らげるこ 亡に有意差はないが（p=0.16）、家族の客に対しては気になる程度を 和らげることに有意差がタられる $(\mathrm{p}<0.01)$ 。

(3)「SF 型」の家族に対する気になる程度において、自分が高い段 上の位置になるLでの評価が低い段下の位置になるDでの評価より
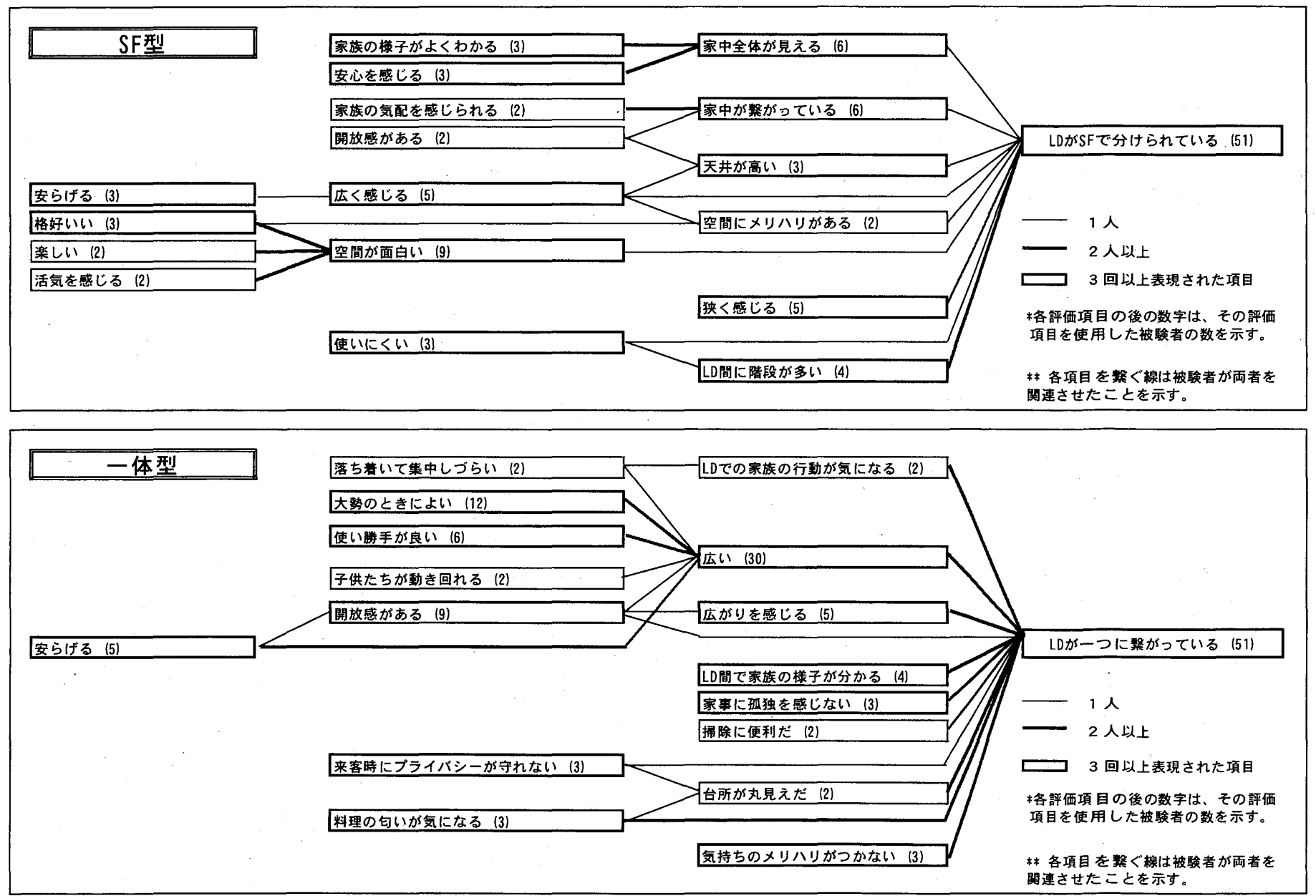

図 3 L D の構成方式の違いによる印象評価構造の比較（定型自由記述による評価） 
高い傾向が見られ $(p=0.06) 、$ 段上より段下で相手が気になると感じ る。

このような L とD での差は、「SF 型」の家族に対する場合に限って 現れる。従ってこの差はその空間で行う行動の違いによるものでは なく、上下の位置関係から生じるもの亡思わ扟る。これを初見ら7に よる、見上げるものは実際より遠く、見下ろすものは近く感じると いう距離感から考えると、気になるということは距離感以外にも何 かに大きく影響を受けることとみられ、更なる検討が求められる。 3 ) コミュニケーション意識注51, 注91

両実験対象の家中でのコミュニケーション意識を、L から D に・L から 2 階にいる家族に声をかけやすいかと様子をわかるかを答えさ せるという方式で評価させた。各評価の全被験者平均値を図 5 に示 す。状況・条件別比較を行い判明した結果を以下に挙げる。

(1)「・体型」は「Lからへ」の評価と「L から 2 階へ」の評価が 極端に分かれる。

(2)「SF 型」は「L からDへ」の場合は「…体型」より低い評価であ るが、「L から 2 階へ」は「一体型」より高い評価がえられ、家中全 体的なコミュニケーションが良いと言える。

\section{3. 画像実験}

\section{3-1. 実験概要}

現場実験では床段差以外の統制されてない他の要因による影響も 多いと考えられる。そこで床段差に加えて他の要因も制御した C G 画 像実験を実施した。具体的には、現場実験の実験対象空間のうち、林 段差のない「一体型」のLD 間において、CGにより様々な高さの床段 差を設けた画像を提示し、同じく「気になる」程度と「声をかけや すい」程度に対する印象評価を行った。同時に空間自体に対する印

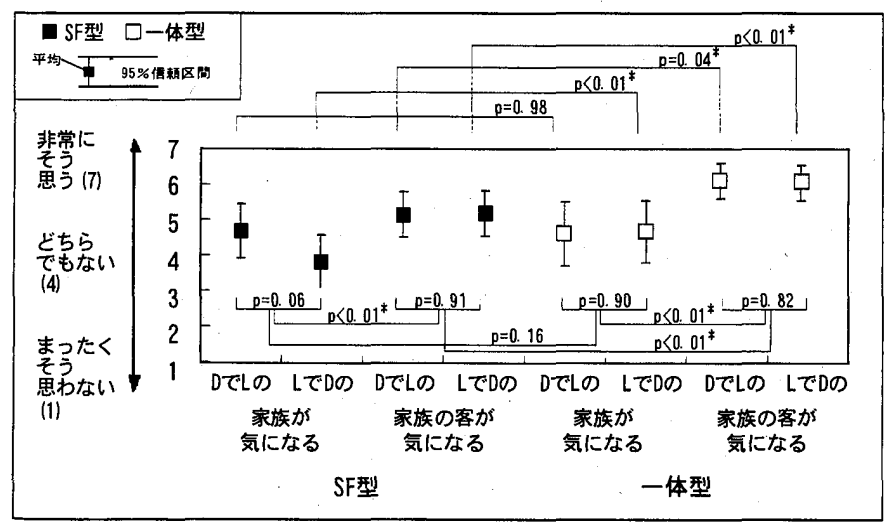

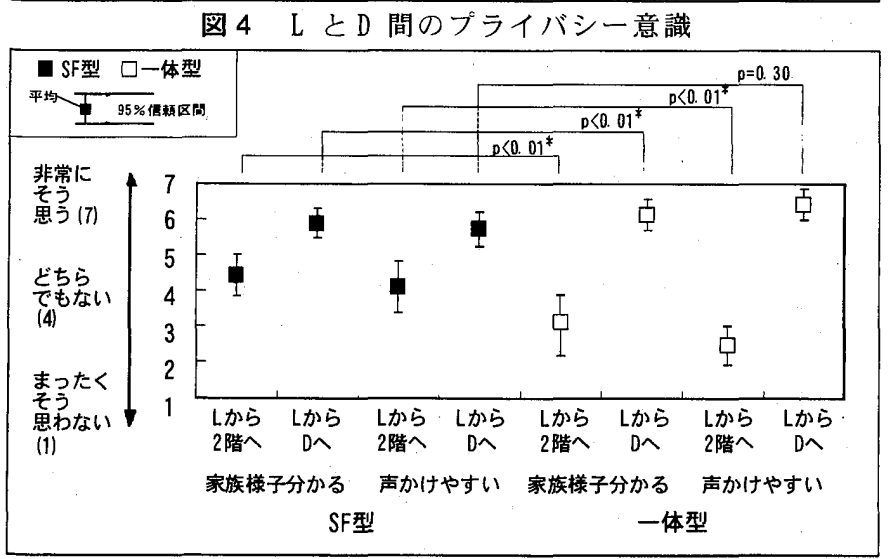

図 5 L とD 間のコミュニケーション意識
象評価も行った。

まず「…体型」の LD 間において、被験者はD で，その人の家族の 一人はL で別々にくつろいでいる場面を想定した。そして「…体型」 の L D において被験者が D のイスに座ってLにいる家族の方を眺めた ときの状態をCG で表したものを基準空間とし、それに実験要因を加 えた評価画像をCGにより作成した注10)。そのCG を用いた画像実験を 通じて実験要因による印象評価の変化をみることにした。

\section{1 ) 実験要因及び評価項目}

実験要因としては床段差の高さを変化させた。なお床段差による 影響を空間を区切る他の手法による影響との比較を行うため、空間 デザイン事典11による空間を区切る手法としての壁，幅，レベル差， 装置・記号，中間領域のうち分けられた両空間が水平に連続してい る壁と装置・記号を実験要因に加えることにした。さらに壁は透過 率で，装置・記号は遮蔽物を用いその高さで細分し、基準空間を含 め 23 種類の空間を設定した。(表 3 、図 6 )。

床段差は込山らの研究結果引を受け、椅子や壁としての機能を果た し印象評価にも変化をみせた $30 \mathrm{~cm}, 45 \mathrm{~cm}, 60 \mathrm{~cm}$ のものと $\mathrm{SF}$ を想定した $120 \mathrm{~cm}$ のものを設定した。また、現場実験の結果から段上と段下によ る差が想定されたため、被験者の上下位置関係による段上と段下を 実験要因として設定した注 11 。 。井形状は床段差と連動して天井にも 段差があるもの（両空間の天井高；2,715m 段上になる空間が基準空間の天井高を維持するもの（段上天井高 2, $715 \mathrm{~mm}$ ，段下天井高 ; $2,715 \mathrm{~mm}+$ 段高) の両方を設定した。

印象評価項目は空間に対する印象と、しにいる人型に対するプライ バシー意識とコミュニケーション意識から構成した。その内容を表 4 に示す。

\section{2) 画像の提示法及び被験者構成}

実験は東京大学工学部…号館環境系実験室にて大学生 40 名 (男性 21 名，女性 19 名)の被験者により行った。CG 作製の際の視野角の設定に あわせ、作成したC G をスクリーンの背面から投影した。提示の設定 を図 7 に示す。被験者は水平視野角が 100 度になる位置であるスク

表 3 画像実験の実験要因となるL D の構成方式

\begin{tabular}{c|c|c}
\hline \multirow{2}{*}{ 㦿段差 (16種類) } & 被験者の位置 & 段上, 段下 \\
\cline { 2 - 3 } & 天井形状 & 段差あり, 段差なし \\
\cline { 2 - 3 } & 段高 & $30 \mathrm{~cm}, 45 \mathrm{~cm}, 60 \mathrm{~cm}, 120 \mathrm{~cm}$ \\
\hline 遮蔽物 (3種類) & 高さ & $60 \mathrm{~cm}, 120 \mathrm{~cm}, 180 \mathrm{~cm}$ \\
\hline 壁 (3種類 & 透過率 & $0 \%, 50 \%, 100 \%$ \\
\hline 基準空間 (1種類) & \multicolumn{2}{|c}{ 区分けなし } \\
\hline
\end{tabular}

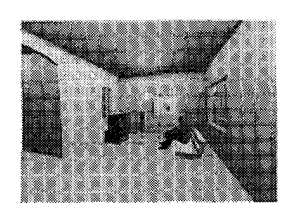

基集空間

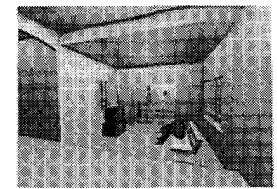

段上- $30 \mathrm{~cm}$

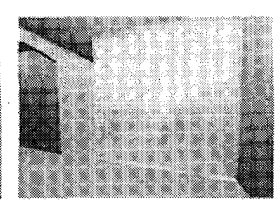

壁-透過率 $50 \%$

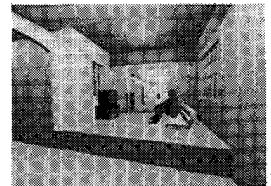

段下 $-45 \mathrm{~cm}$ (段差あり)

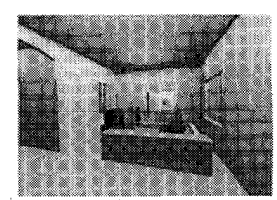

遮蔽物 $-60 \mathrm{~cm}$

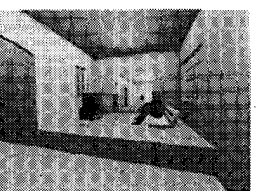

段下 $-45 \mathrm{~cm}$ (段差なし)
図 6 実験要因となるL D の構成方式 

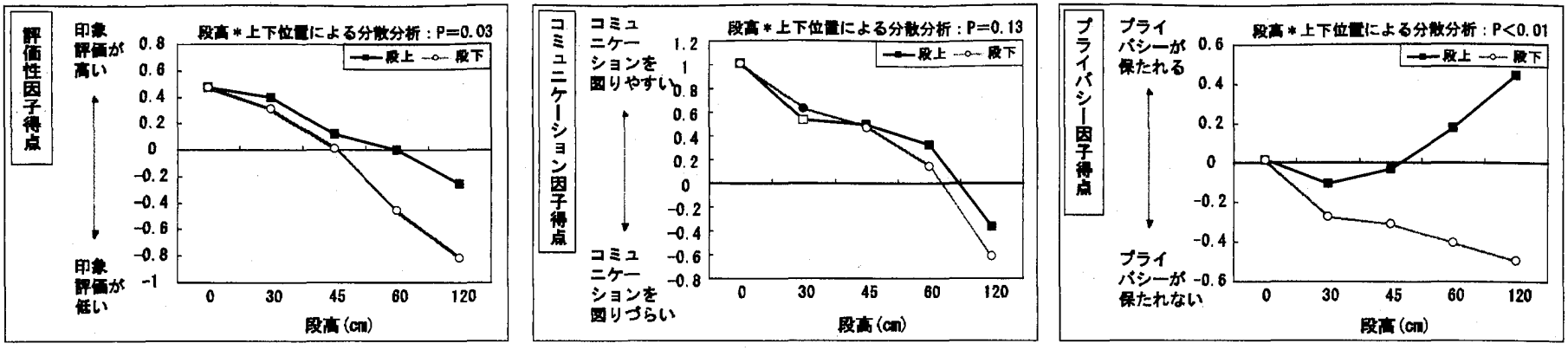

図 9 各因子得点の段高及び上下位置による評価の平均
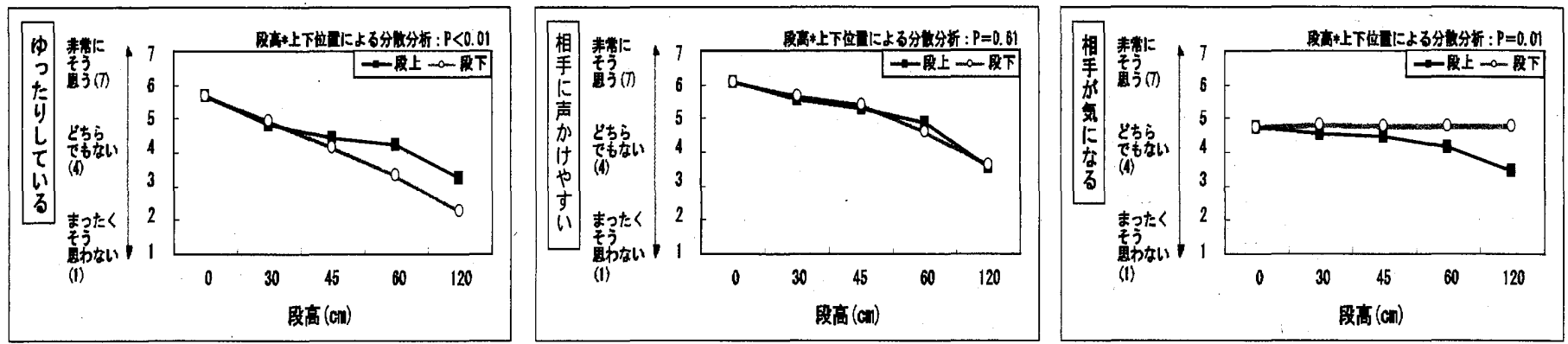

図 10

各評価項目の段高及び上下位置による評価の平均

より段高が低いにも関わらず居心地などの空間に対する印象は悪い

ことが分かった。

2-2）コミュニケーション因子得点

コミュニケーション因子得点が最も高い空間は基準空間である。 次いで段下 $30 \mathrm{~cm}$ ，段上 $30 \mathrm{~cm}$ ，段下 $45 \mathrm{~cm}$ ，段上 $45 \mathrm{~cm}$ ，透過率 $100 \%$ の壁，段 上 $60 \mathrm{~cm}$ ，段下 $60 \mathrm{~cm}$, 遮蔽物 $60 \mathrm{~cm}$ 順であり、床段差の段高が低いほどコ ミュニケーションの機会を持ちやすいと考えられる。またガラスの 壁を想定した透過率 $100 \%$ の壁は $45 \mathrm{~cm}$ と $60 \mathrm{~cm}$ の間の床段差程度と等し い開放感やコミュニケーションの機会が得られるといえる。コミュ ニケーション因子得点が最も低い空間は透過率 $0 \%$ の壁である。次い で遮蔽物 $180 \mathrm{~cm}$ ，遮蔽物 $120 \mathrm{~cm}$ ，段下 $120 \mathrm{~cm}$ ，透過率 $50 \%$ の壁，段上 $120 \mathrm{~cm}$ の順であり、これらの得点はマイナスである。以上から相手が見え なくなる、もしくは段高が高いほどコミュニケーションの機会は持 ちにくいと言える。全体的に視覚的連続性を多く持つほど高い評価 が得られる自明な結果が得られた。なお段上と段下による違いはな かった。

\section{2-3) プライバシー因子得点}

プライバシー因子得点が最も高い空間は透過率 $0 \%$ の壁である。次 いで遮蔽物 $120 \mathrm{~cm}$ ，遮蔽物 $180 \mathrm{~cm}$ ，段上 $120 \mathrm{~cm}$ ，段上 $60 \mathrm{~cm}$ ，基準空間の順 である。得点の最も低い空間は段下 $120 \mathrm{~cm}$ である。次いで段下 $60 \mathrm{~cm}$, 段下 $45 \mathrm{~cm}$ ，段下 $30 \mathrm{~cm}$ ，透過率 $100 \%$ の壁，透過率 $50 \%$ の壁，段上 $30 \mathrm{~cm}$ ，段 上 $45 \mathrm{~cm}$ ，遮蔽物 $60 \mathrm{~cm}$ の順であり、これらの得点はマイナスである。以 上から相手が見えない、もしくは自分が $60 \mathrm{~cm}$ 以上の段上にいるとき に相手が気になることを和らげると考えられる。また段上において も $30 \mathrm{~cm}, 45 \mathrm{~cm}$ 程度の木段差は基準空間よりもプライバシーが守られに くいと評価される。なお基準空間が透過率 $50 \%$ の壁や遮蔽物 $60 \mathrm{~cm}$ に より区切られている場合よりも高く評価されていることに関しては 普段の生活で最も親しみのある類型であるためではないかと思わ的 るが、これに関しては更なる検討が求められる。

\section{3 ) 床段差による検討}

3 つの因子得点を用いて各因子の段高と上下位置及び天井形状に
表 6 . 各因子の段高，上下位置，天井形状による分散分析

\begin{tabular}{|c|c|c|c|}
\hline 要因 & 評価性因子 & 民゙ライバシー因子 & 三ニニニーション因子 \\
\hline 段高 & $\left\langle 0.01^{*}\right.$ & 0.37 & $\left\langle 0.01^{*}\right.$ \\
\hline 上下位置 & $\left\langle 0.01^{*}\right.$ & $\left\langle 0.01^{\circ}\right.$ & 0.14 \\
\hline 天井形状 & 0.19 & 0.79 & 0.65 \\
\hline 段高*上下位置 & $0.03^{*}$ & $\left\langle 0.01^{* *}\right.$ & 0.13 \\
\hline 段高*天井形状 & 0.65 & 0.94 & 0.72 \\
\hline 上下位置 *天井形状 & 0.35 & 0.81 & 0.06 \\
\hline 段高*上下位置*天井形状 & 0.94 & 0.54 & 0.36 \\
\hline
\end{tabular}

よる三元配置の分散分析を行った。その結果を表 6 に示す。評価性 とコミュニケーション因子において段高による主効果が確認された。 評価性とプライバシー因子において上下位置による主効果が確認さ れ、段上でより高い評価が得られた。なお、評価性とプライバシー 因子において段高と上下位置による交互作用が確認された（図 9)。評 価性因子とコミュニケーション因子は段高が高いほど評価が下がる。 特に段高 $60 \mathrm{~cm}$ からはその幅が大きくなり、コミュニケーション因子 の段上及び段下と評価性因子の段下の $60 \mathrm{~cm}$ からはさらに大幅に下が る。これらの傾向は両因子の各項目にも見られる。そのうち「ゆっ たりしている」と「相手に声かけやすい」を例として図 10 に示す。 プライバシー因子は、段上の段高 $60 \mathrm{~cm}$ 以上では段高が高くなるほど プライバシーが保た狆るが、段下では段高が高くなるほどブライバ シーが保たれない。このような傾向は「相手が気になる」との評価 項目の段上でも見られるが、段下での変化は僅かである。

\section{4. 考察}

本研究は、実空間を利用した現場実験とCGによる画像実験を通じ て、床段差により分かれている各空間での、プライバシー意識とコ ミュニケーション意識の変化を見たものである。その結果、現場実 験の「S F 型」は分かれた両空間にいる相手が気になる度合いを和ら げることや、段下より段上でプライバシーは保た机ることが分かっ た。なお、画像実験により、段高 $60 \mathrm{~cm}$ 以上の段上でプライバシー意 識の評価が高くなることと、段下より段上でブライバシーが保たれ 
ることを確認することにより、現場実験のブライバシ一意識に対す る結果が床段差による影響であることを検証した。

一方、休段差を設けることは、段上も段下も同時に発生すること を意味する。ここから、空間デザインにおいて床段差を計画すると きは、段上と段下になる各空間の行動設定に求められるブライバ シ一の度合いに合わせた計画が必要であると言える。筆者の過去の 研究 ${ }^{81}$ によると、床段差で分か机ているリビングルームとダイニング ルームの形態は、リビングルームが低くダイニングルームが高い場 合が多く見られるが、一般的には、ダイニングルームよりリビング ルームでの行動に、より高い水準のブライバシーが求めら机ると考 えられる。ここから、リビングルームとダイニングルーム間に床段 差を設ける場合は、リビングルームをダイニングルームより高く設 けるか、あるいは、リビングルームを低く設ける場合に、視線が当 る部分の家具配置やバーティション設置などにより開放感を損なわ ない範囲でリビングルームのブライバシーを補うための視線処理に 対する工夫が求めら扎ると考えら狆る。

なお、本実験の垷場実験と画像実験から空間に対する印象及びブ ライバシー意識の段上と段下での評価において有意差が確認された。

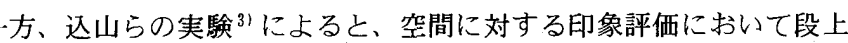
と段下での差はほとんど見られなかった。このことから、「気にな る」を用いて評価した「プライバシー意識」は、床段差のもつ空間 そのものに対する印象とは異なり、上下位置の影響が強いことと予 想されるため、床段差以外の他の要因を制御した実験空間における 更なる検討が求められる。

\section{5. まとめ}

現場実験によって、㦿段差で分けられている空間に対して以下の ことが得られた。

(1)床段差で分けら机ている空間は、視覚的に分離さ扎狭く見えて も、図1のLD のようにボリュームの異なる空間の連続により各空間 に個性や特徵があると感じさせる。ここから、空間を多様に感じさ せ、心理的に広く感じさせる。

(2)リビングルームとダイニングルームの間のブライバシー意識に おいて、床段差で分けられている空間は、リビングからダイニング、 ダイニングからリビングにいる相手が気になる度合いを和らげる。 なお「SF 型」の家族に対しては、高い位置のリビングルームでダイ ニングルームを見下ろす場合と、低い位置のダイニングルームでリ ビングルームを見上げる場合での評価には有意な差が見られた。

次に、現場実験の結果が床段差による影響であるかを明らかにす る月的でコンピューター・グラフィックによる画像実験を行った結 果、以下のことが得ら扎た。

(1)評価性因子とブライバシー因子において、段上と段下での有意 差が確認され、段上でより高い評価が得られた。ただし、その差は 段高 $45 \mathrm{~cm}$ までは僅かであり、60cm 以上で大きくなる。

(2) $60 \mathrm{~cm}$ の床段差においての段上ではブライバシーが守られやすく、 コミュニケーションの機会を持ちやすいと同時に、居心地などの空 間に対する印象も良いということが分かった。

本研究を遂行するにあたり、実験空間およびデー夕の提供など 数々の御協力をいただいた東急ホーム株式会社 E B H住宅研究所に 記して謝意を表します。
注

注 1) 用象評価においては、椅子としての機能や”磵を二つに分節することに影哴 を及ぼすなど、段の高さによって各々と翼なる意味を持つとしている。さら に450m吅より畐くなるとゆったりした感じが減少しに迫感が增加する状態に なるという結果を得ている。また天井高の1:算によりこれらのゆったりした 感じの滅少やた迫感の増加は抑えることができると述べている。居場听の選 抧においては、被験者 3 人が共に居るとき、床段差により 3 人の艮場所が段 差部分と段の上とトに分かれるという結果から、床段差が空間を幾つかの領 域に分ける仕掛けとして働いていると述べている。

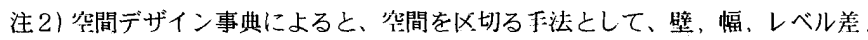
装置・就少と中間領域を設けることの斤つを举げており"、このうち視覚的 な繫がりを持つ開かれた部分が大きく、さらに分かれた領域間の水平距離を 短く慗いでいるのがレベル差と芌える。また、ここで活うレベル差は外部空 間においての地面の䯩低差を含んでおり、これを室内鄙間に限定して言うと 床面の高低差を意味する床段差と考えられる。

注 3) 筆者の過去の研究到によると、新建築住宅特集(1986 年 5 月〜 1997年 12 月) に揭载さ机た住宅を分析した結果、床段差は亡にL L Dの間，L と和室の間， 嫏トと個室の間などに多く設けら扟ており、家全体がSFになっている場合も 多く見られにた。特にSF は、敷地の前面の幅が狭く奥に細長い形になっている 場命、1階の・部を駐車スベースに利用する場命、建物の一部に半地下室を設 ける場合などで多く見ら扎、空間の効辫的な利用だけに限らず、建物の奥ま での風通しと採光の効果もあると考えられいる。

注 4）事典的意味での「ブライバシー」は、「個人の私生活や家庭内の私事。ま た、そ饥を、他の個人や社会に知ら机ず、干渉を受けない権利」を意味する

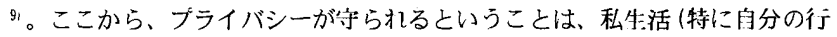
動)が相手により干渉さ扑る程度を用いて定量化できると考えら犼。こして 白分の行動が相手により干渉されるるいうことを逆にいうと、自分で好きな 行動をとるのに相手が気になることと考えられる。以にのことから、本研究 の住宅室内家族共用空間における「ブライバシ一意識」は、LD の間の各空間 で家族構成員が各々別に自分の好きな行動をとることと想定させ、現場実験 はLからD及びDからLに、畞像実験はDからLにいる家族の存在に対して「相

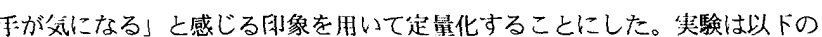
ように教示し、7段階の SD 法により答えてもらった。『今间お過ごしになった モデルハウスのリビングメはダイニングルームにご自分と相手の人が各々分 かれてて、雑誌を読みながら休むなど自分の好きな行動をとっていると仮定し た場合、以下の設問に対してお答えください。(1)自分がリビングルームにい るとき、ダイニングルームにいる他の家族の方がどれぐらい父になりますか。 (2)自分がダイニングルームにいるとき、リビングルームにいる他の家族の方 がどれぐらい気になりますか。』さらに、比較対象空間の間においてブライバ シ一意識の変化をより詳しくみるため、家族に加え家族の客が来ていること を想定させ、家族の客に対して詊価してもらった。

注う）家族の「コミュニケーション」に対する研究では、視子がお百いに関して

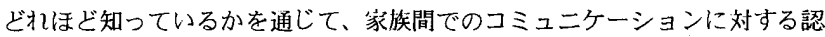
識の違いを指摘したもの101や、過去の映油の場面の中で家族団らんのシーン を分析することによって家族のコミュニケーションが行わ机た空間の特徽を まとめたもの川などがある。‥方、本研究でのコミュニケーション、つまり 床段差がもつ「繋ぐ」から発想を得た家族間のコミュニケーションは、様々 な社会的問題を背景に家族間のコミュニケーションの機会が隇少しつつある 現代家族の状沿を踏まえ、「コミュニケーションの機会」に着甘した。さらに、 コミュニケーションとは、并の場の䇰团父や父分及び性格など、様々な特性 が関わるものであり、これを一概に定䑁化することは困難であることを考え ると、コミュニケーションの寒体の代わりに、その能性としてのコミュニ ケーションの機会に着目することは意味があると考えら狆る。心理学では、 ある冏体の行動変化 (発信)に応じて别の固体に行動変化(応答) が生じた場命 を、画者の間にコミュニケーションが成立していると見ている1313。ここか ら、コミュニケーションを定星化するためには、倜体間の発信と応答がどれ ほど行われてているかを見ることが重要であると考えられてる・方、ある固体 の「発信」に态じて別の固体に「伈答」が多く生じるためには、まず、発信 の頻度が多くなること、つまり、気軽く発倐できることが必慗であると考え ら机るさらに、各问常生活の行動をとりつつ、家族間のちょっとした 会話の発端を造ることや、家族の父配を感じられる心の慗がりが、コミュニ ケーションの機会になれると考えられて。以トのことから、本研究の住宅室 内における「コミュニケーション意識」は、LD の間の各空間で家族構成員が 各々別に自分の好きな行動をとるにおいて、LからDにＤ加らにいる家族 に対して「声をかけやすい」と「様子をわかる」との用像を用いて定星化す ることにした。

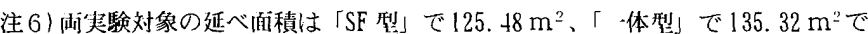


あり、規模面で統湖苟 (平成 15)による川本の持ち家の 1 住宅当たり延べ的秥 $\left(121.67 \mathrm{~m}^{3}\right)^{14}$ に近いことから、11本住宅の 般的規模であると考元られる。な お、「SF 型」のLとDは階段で繋がれてており、威1の平岶に:に濃く塗ってある

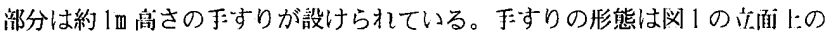
「形の網掛け内のような手すり子タイブ（格子部材を縦に配列し、面を形成 していることが特徴)である。

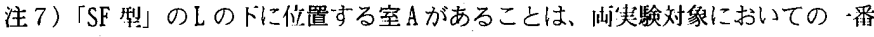
の䒹いではあるが、室Aが玄関から目接に慗いでいていからは見えないため、 LD 間の印象を評価することにおいては影響が大きくないと判断した。また、 「SF 型」はSF といえども LD の間に位置する階段が 2 階まで慗がるため純粋に

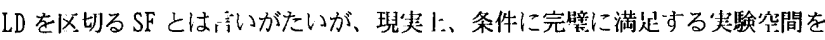
探すのは困難であったため、奉際の㬰験に心じる被験者に対する教ふ文にお いて、なるべくLD間の構成方式に注月して念えてくれるようにとお願いした。

注 8） $\mathrm{T}$ 社社囬は、住まいの睘境と筷病予防や健康增進の関係について研究を 行っている下社住宅研究所の研究員であり、装間に対する意識が高门と考え ら机る。

注 9) ブライバシ一意識に関しては、家族に対する評俇において被験者の性格など の特性により坛が明確でない結果も予想されるため、家族に加え家族の客に 対する評湖を補った。コミュニケーション意識に関しては、LD 間では一体犁 の方が高く評湖さ犼ことが自明であるが、もしLD間ではブライバシーの封 られにくいため倜公を利用するとすると、それれはLD間のコミュニケーション を評価する以前の問題に逢着することから、家中での全体的なコミュニケー ション意識を用いて両実験対象での比較を行うことにした。

注 10）本研究の画像害験は、LD の間の各空間で家族構成員が各々別々に自分の好 きな行動をとることを想定させ、Dからしにいる家族の存在に対して詊伍する

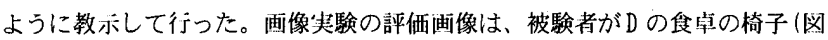
2のれ印に座って、Lのソファーに座っている家族の一人に対する印象を評佂 する場面を仗定し、CGにより製作した。なお、頭部を固定し、眼球を運動さ せて注視できる篹䎴 (注視野) は水平方向 $100^{\circ} 151$ とさ扎いることより、提示

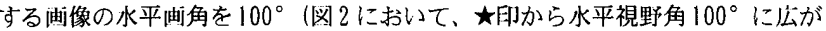
る網掛けの部分に刘応) と設定した。また、自分の好きな行動をとることを想 定させるという実験条件から、被験者の位置はスクリーンと归ではなく、横 から見る斜めの位置（网7参照）とし、このような状態で被験星がスクリーン の闻像を見たとき、油像内の事物の仙置や方向を奏空間と 致させるため、提 ホする元の幽像すなわちCGで作成した画像（図6 参照)には、あらかじめ逆 変換を加えている。よって、図6の画像には歪みが見ら机るが、尧験で最終的 に被験者が見る画像には华みはない。このような提示の設定は、宗方ら ${ }^{161}$ よる画像尖験においての視野設定に関する研究を参考にしたものである。ま た、本头験は、分か狆た各空間に留まって、日常牛活の行動を行っているこ とを仗定しているため、被験者の姿勢は座位に設定した。

注 11) 玩場実験においてのブライバシ一意識のLとDでの違いが、その究間で行う 行動の違いよりトドの位置関係による差であることと思わ㧈るため、コミュ ニケーション意識に対しても L とDでの車方の評価が求められると思わ犼。 しかし、本実験の展示場の利用時間の制約条件上、2006 年 2 月以降は使用が 不叮になり、実験器間を利用した補疋実験を行うことが困難であったため、こ れに関して画像実験を用いて詳しく検討することにした。

注 12）《子分析絬果により、「開放感」，「一体感」は、評佂性因子とも相関が認め られるが、コミュニケーション因子との相関がより高いことを分かった。ま た、「相手が近くにいると感じる」はコミュニケーション因子との相関が最も 漓いが、ブライバシー因子との相関も槀い。ここから、「相手が近くにいると 感じる」は親近感にも慗がるが、近いという距離感から気になることとも関 連があると考えら枦。

注 13) 込山らの実験3 では「空間を2 つに感じる」以外の項月において段トと段 下による有意な差は無く、特に本実験の評価項月と類似な「ゆったりした感 じがする」と「派迫感を感じる」に関してもほとんどの差がなかった。

\section{参考文献}

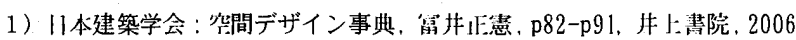

2) 11 本建築学会 : 建築人間 $\Gamma$ 学事典，古瀨敏，p73，彰目社，1999

3）込山敦司・初見学：休段差が室空間の心理的・機能的評伍に及ぼす影響 1 日

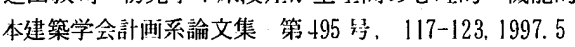

4）高橋洋子・大崎㳯史・込山敦司・陃出利彦・初兒学・高橋第志 : 床レベル差 とその平面形態が空間の朋象評価と体験者の行動に及ぼす影響门本建築学会

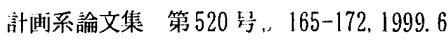

う）橋本都子・西汁和彦・高橋公子・高橋䉆志 : 尖験による対人距離からみた心 理的领域の平面方们の公がりに関する考察 11本建築学会計涸系論文集 第 485 号, 135-142, 1996.7
6) 林佼克:Excel で学ぶテキストマイニング入門, p108，オーム社， 2002

7) 内滕惠介・初少学：見にばと見トろしの趾離感: 趾離の認知に関する研究山本 建築学会学術講演概要集 1993. E, 985

8）金銀熙・八滕後猛・野村鹳；日本人学大学院理I:学研究科建築専政修士論文梗 概集, 1998

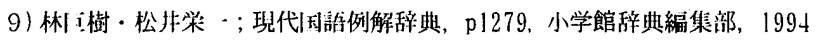

10）滕野激子・北浦かほる：子どもの成佥によるコミュニケーション鼠の分析, 視 子のコミュニケーションと家族室に関する研究 その1 11 訨建築学会学術講 演概奖集 $2004, \mathrm{E}-2$, p. 415

11）田中徽也・宇杉和夫：小洮映呐「お早う」の住宅におけるコミュニケーショ ン・シーンについてー建築部荫のための空間シーンの粠成及び分析に関する 基礎的研究一11本建築学会計伷系論文集 第603聍，23-28，2006.6

12「コミュニケーション」『フリー白科事典 ウィキベディアは本語版』。2007 年 5 月 1911 (土) $06: 16$ LRL : hltp://ja wikipedia org

13）鹿取公人・杉本敏夫：心理学「第2 版」, p175, 東京大学出版会, 2004

14）統計局: 平成 15 年住宅・土地統計調查の解説一 1 住:宅当たり延べ而積及び 1

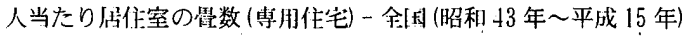

15） 11本建築学会：建築設㖕資料集成 3 単位空間 I (視野)，pp. 42 ，丸善株式会 社, 1980

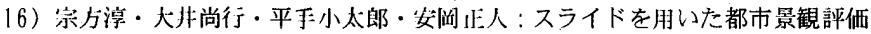

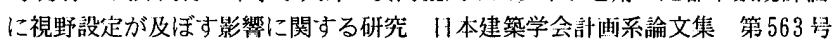
69-75, 2003. 1

(2007年 2 月10日原稿受理，2007年 7 月 18 日採用決定) 